\title{
Effects of Variable Sulfur Supply on the Accumulation, Subcellular Distribution, and Chemical Forms of Cadmium in Hydrilla verticillata
}

\author{
Guoxin Li ${ }^{1 *}$, Qingsong Li ${ }^{1}$, Lei Wang', Guoyuan Chen ${ }^{1}$, Dandan Zhang ${ }^{2}$ \\ ${ }^{1}$ College of Environmental Sciences and Engineering, Xiamen University of Technology, Xiamen, China \\ ${ }^{2}$ Institute of Urban Environment, Chinese Academy of Sciences, Xiamen, China
}

Received: 7 January 2018

Accepted: 21 February 2018

\begin{abstract}
Indoor experiments were performed to determine the accumulation, subcellular distribution, and chemical forms of $\mathrm{Cd}$ at five $\mathrm{S}$ levels in Hydrilla verticillata. The $\mathrm{Cd}$ content increased from $1.229 \mathrm{mg} / \mathrm{g}$ to $3.329 \mathrm{mg} / \mathrm{g}$ in leaves, and decreased from $2.794 \mathrm{mg} / \mathrm{g}$ to $1.023 \mathrm{mg} / \mathrm{g}$ in roots, respectively. Excess $\mathrm{S}$ supply stimulated $\mathrm{Cd}$ assimilation in leaves as $\mathrm{Cd}$ accumulation was inhibited in roots. The $\mathrm{Cd}$ content in leaves at subcellular levels revealed that $\mathrm{Cd}$ was stored mainly in the soluble fraction (71.9-88.2\%), and in small quantities in the cell wall (6.1-22.4\%) and cell organelles (4.8-6.9\%). As $\mathrm{S}$ increased, the $\mathrm{Cd}$ content in leaf soluble fractions and cell walls increased remarkably. The content of $\mathrm{NaCl}$-extracted $\mathrm{Cd}$ in leaves increased as $\mathrm{S}$ supply increased, and this parameter was much higher than that of other $\mathrm{Cd}$ forms. In leaves, the $\mathrm{Cd}$ concentrations in the cell walls were significantly correlated with the chemical forms extracted by $\mathrm{HAc}, \mathrm{HCl}$, and $\mathrm{NaCl}$, with correlation coefficients of $0.985,0.964$, and 0.957 , respectively. The high correlation indicated that $\mathrm{Cd}$ in soluble fractions or cell walls was mainly in the form of pectates/protein, phosphate, and oxalate. The application of $\mathrm{S}$ alleviated Cd-induced oxidative stress by increasing the proline accumulation. Furthermore, sulfhydryl proteins such as glutathione and cysteine may play a crucial role in the reversal of Cd-induced oxidative stress.
\end{abstract}

Keywords: Hydrilla verticillata, sulfur, cadmium, subcellular distribution, chemical forms

\section{Introduction}

Heavy metal pollution has been considered a global environmental problem because heavy metals elicit toxic

*e-mail: versatile2010@sina.com effects, persist in aquatic environments, and accumulate in increasing quantities inside living organisms along the food chain [1]. For example, cadmium $(\mathrm{Cd})$ is a toxic and highly water-soluble element; $\mathrm{Cd}$ is readily taken up by plants, although this heavy metal is not essential for plants and is toxic to aquatic plants at cellular, physiological, biochemical, and molecular levels [2]. 
Cd toxicity causes several symptoms, including growth retardation, photosynthesis inhibition, enzyme induction and inhibition, water interaction disruption, and ultrastructural changes [3-5].

Less expensive and destructive remediation strategies than current approaches have been extensively investigated [6-9]. For instance, phytoextraction is a valuable technique used to remove pollutants from the environment using plants. This technique has been employed to remediate contaminated water and soils and remove metals from sludge. Compared with other cleanup technologies, this technique provides many advantages, including low cost, in situ development, and minimum environmental impact [10]. Submerged macrophytes, which play important structural and functional roles in aquatic ecosystems, can accumulate metals [11] and be used to remove heavy metals from wastewaters. Metals adsorbed by plants can be trapped by the negative charges of the cell wall or be taken up into the cell cytoplasm and compartmented in some nonfunctional organs, such as vacuoles [12]. Adsorbed metals, such as $\mathrm{Cd}$, can also be extracellularly excreted [13]. Cd-induced stress in plants can be alleviated through numerous strategies. For example, $\mathrm{Cd}$ detoxification occurs mainly through chelation via sulfur (S)-containing ligands, such as glutathione (GSH), cysteine (Cys), and phytochelatins (PCs), which are GSH polymers [14].

Submerged plants can absorb nutrients and chemicals from overlying water and sediments because they are exposed to both environments [15]. $\mathrm{S}$ is an essential macronutrient that regulates plant growth, development, and responses to biotic and abiotic stresses. Under $\mathrm{Cd}$ stress, $\mathrm{S}$ improves growth, increases anti-oxidative capacity, and reduces ROS and lipid peroxidation. A high amount of sulfate in a culture medium promotes high $\mathrm{Cd}$ tolerance because of an increase in thiol compound biosynthesis [16]. S addition can restrain Cd uptake, increase biomass, and promote nonprotein thiol (NPT) pool synthesis, including PCs and GSH synthesis, in rice to alleviate $\mathrm{Cd}$ toxicity [17]. High $\mathrm{S}$ availability in soil protects mustard from $\mathrm{Cd}$ toxicity by improving AsA and GSH content in leaves [18]. $\mathrm{S}$ deficiency increases the level of oxidative stress and restricts the GSH biosynthesis pathway in Arabidopsis thaliana under Cd stress [19]. Therefore, high S levels can stimulate high GSH levels to enhance Cd tolerance in plants. $\mathrm{S}$ can decrease $\mathrm{Cd}$ accumulation and alleviate $\mathrm{Cd}$ toxicity in plants because of the formation and precipitation of detectable CdS [20]. However, to our best knowledge, the mechanisms by which $\mathrm{S}$ affects the subcellular distribution or chemical forms of $\mathrm{Cd}$ in plants have yet to be described.

The subcellular distribution and chemical forms of heavy metals may be associated with metal tolerance and detoxification in plants [21]. Ramos et al. [22] observed that $\mathrm{Cd}$ is mainly present in the cell wall fraction of lettuce. Conversely, Wang et al. [23] found that the highest amount of $\mathrm{Cd}$ is in the form of pectates/protein- integrated $\mathrm{Cd}$ and insoluble Cd-phosphate complexes. Hence, consistent results have yet to be obtained, and the relationship between subcellular distribution and chemical forms of heavy metals was still unclear.

Hydrilla verticillata is a common aquatic angiosperm, which is distributed worldwide and characterized by a rapid growth rate; this species has been described as a potential accumulator of heavy metals, such as $\mathrm{Pb}, \mathrm{Hg}, \mathrm{Cu}, \mathrm{Cd}, \mathrm{Cr}, \mathrm{Ni}$, and $\mathrm{As}$ [24-27]. However, the effects of $\mathrm{S}$ on the subcellular distribution and chemical form of $\mathrm{Cd}$ in $H$. verticillata have been rarely reported. Antioxidants such as GSH are important molecules contributing to the tolerance of plants to $\mathrm{Cd}$. Therefore, studies should be performed to determine whether the variation of a source of $\mathrm{S}$ in the medium affects the subcellular distribution and chemical forms of $\mathrm{Cd}$ through an interactive effect.

This study aimed to assess the accumulation, subcellular distribution, and chemical forms of $\mathrm{Cd}$ in $H$. verticillata under the effect of $\mathrm{S}$ and to investigate the existence of an interaction between $\mathrm{Cd}$ and $\mathrm{S}$ as a factor that altered $\mathrm{Cd}$ toxicity. This study provided useful information for the phytoremediation of $\mathrm{Cd}$ and the development of techniques to reduce $\mathrm{Cd}$ toxicity in aquatic plants in the presence of $\mathrm{S}$.

\section{Materials and Method}

\section{Plant Materials and Cadmium Treatments}

H. verticillata was collected from unpolluted bodies of freshwater in Nanjing, China. For experimental studies, plants of approximately the same height $(15 \mathrm{~cm})$ and fresh weight $(8.0 \mathrm{~g})$ were selected and washed with running tap water and distilled water; then they were kept in a glass aquarium containing 1/10 Hoagland solution for 2 weeks at photosynthetic photon flux density of $114 \mu \mathrm{mol}\left(\mathrm{m}^{2} \mathrm{~s}\right)^{-1}$ for a photoperiod of $14 \mathrm{~h}$ at a temperature of $25 / 20^{\circ} \mathrm{C}$ (day/night). There were five sets of experiments, each having a different level of $\mathrm{S}$ supply $(0,0.25,0.5,1$, and $2 \mathrm{mmol} / \mathrm{L})$. After keeping the plants in different sets of $\mathrm{S}$ supply for 5 days, they were exposed to several $\mathrm{S}$ and $\mathrm{Cd}$ treatments carried out as follows: $\mathrm{S}\left(\mathrm{Na}_{2} \mathrm{SO}_{4}\right) 0,0.25$, $0.5,1$, and $2 \mathrm{mmol} / \mathrm{L}$ with $\mathrm{Cd}\left(\mathrm{CdCl}_{2}\right) 100 \mu \mathrm{mol} / \mathrm{L}$. At the end of the experiment (after $7 \mathrm{~d}$ exposure to $\mathrm{Cd}$ and $\mathrm{S})$, plants were separated into roots, stems, and leaves, and then immediately frozen in liquid $\mathrm{N}_{2}$ and kept frozen until use. All experiments were performed in triplicate.

\section{Cadmium Subcellular Distribution}

Fresh plant materials $(0.20 \mathrm{~g})$ were homogenized in prechilled extraction buffer (comprising $0.25 \mathrm{~mol} / \mathrm{L}$ sucrose, Tris- $\mathrm{HCl}$ buffer solution ( $\mathrm{pH} 7.5$ ), and $1.0 \mathrm{mmol} / \mathrm{DL}$-dithioerythritol) with a chilled mortar and pestle. Cells were separated into three fractions, 
namely cell wall, soluble fraction, and an organellecontaining fraction, using the differential centrifugation technique as suggested by Weigel and Jager [28] with some modifications. The homogenate was centrifuged at 3,000 rpm for $15 \mathrm{~min}$, and the precipitation was designated as cell wall fraction, consisting mainly of cell walls and cell wall debris. The resulting supernatant solution was further centrifuged at $15,000 \mathrm{rpm}$ for $45 \mathrm{~min}$. The resulting precipitate was referred to as the "cell organelles fraction" and the supernatant solution was referred to as the "soluble fraction." All steps were performed at $4^{\circ} \mathrm{C}$. The three separated fractions were then dried and wet-digested for $\mathrm{Cd}$ analysis.

\section{Chemical Formation of Cadmium}

The chemical forms of $\mathrm{Cd}$ were determined using the method described by Wu et al. [29]. The experiment was carried out with the designated solutions in the following order to determine the chemical forms of Cd in different parts of $H$. verticillata: 1) $80 \%$ ethanol, extracting inorganic $\mathrm{Cd}$ giving priority to nitrate/ nitrite, chloride, and aminophenol $\mathrm{Cd}$; 2) deionized water, extracting water-soluble $\mathrm{Cd}$-organic acid complexes and $\left.\mathrm{Cd}\left(\mathrm{H}_{2} \mathrm{PO}_{4}\right)_{2} ; 3\right) 1 \mathrm{M} \mathrm{NaCl}$, extracting pectates and protein-integrated $\mathrm{Cd}$; 4) $2 \%$ acetic acid (HAc), extracting undissolved $\mathrm{Cd}$ phosphate, including $\mathrm{CdHPO}_{4}, \mathrm{Cd}_{3}\left(\mathrm{PO}_{4}\right)_{2}$, and other Cd-phosphate complexes; and 5) $0.6 \mathrm{M} \mathrm{HCl}$, extracting $\mathrm{Cd}$ oxalate. $\mathrm{Cd}$ was not detected in the residues because of its low concentration in the samples.

Frozen tissues were homogenized in extraction solution with a mortar and a pestle, diluted at a ratio of 1:100 (w/v), and shaken for $22 \mathrm{~h}$ at $25^{\circ} \mathrm{C}$. Afterward the homogenate was centrifuged at $5,000 \times \mathrm{g}$ for $10 \mathrm{~min}$, obtaining the first supernatant solution in a conical beaker. The sediment was resuspended twice in the extraction solution and shaken for $2 \mathrm{~h}$ at $25^{\circ} \mathrm{C}$ and centrifuged at $5,000 \times \mathrm{g}$ for $10 \mathrm{~min}$. The resulting supernatant was pooled from the suspension and each of the five extraction solutions was centrifuged. Each of the pooled supernatant solutions was evaporated on an electric plate at $70^{\circ} \mathrm{C}$ until a constant weight was obtained and digested with concentrated nitric acid.

\section{Digestion and Analysis of Cadmium Content}

Before metal analysis was performed, all plant parts, cell walls, and cell organelle fractions were wet-digested in $5 \mathrm{~mL}$ of concentrated $\mathrm{HNO}_{3}$ and then diluted with ultrapure water. In the case of the soluble fraction, $5 \mathrm{~mL}$ of concentrated $\mathrm{HNO}_{3}$ was added to $1 \mathrm{~mL}$ of solution before metal content analysis. Cd concentration was measured using either a flame or a furnace atomic absorption spectrophotometer (AASM6, Thermo Elemental, USA). A reagent blank and a certified reference material (bush twigs and leaves, GBW07602 from the National Research Center for Standard Materials in China) were included for quality assurance. Repeated analysis of the reference material gave $0.135 \pm 0.08 \mathrm{mg} \mathrm{Cd} \mathrm{kg}{ }^{-1} \mathrm{DW}$, which is in accordance with the certified value of $0.14 \pm 0.06 \mathrm{mg} \mathrm{Cd} \mathrm{kg}^{-1} \mathrm{DW}$.

\section{Determining the Contents of Proline, Cys, and GSH}

Proline content in leaves was determined spectrophotometrically by adopting the ninhydrin method of Bates et al. [30]. Fresh leaf samples (about $0.3 \mathrm{~g}$ ) were homogenized in $3 \mathrm{~mL}$ of $3 \%$ sulphosalicylic acid. The homogenate filtrate was reacted with $1 \mathrm{~mL}$ each of acid ninhydrin and glacial acetic acid for $1 \mathrm{~h}$ in a test tube and placed in a water bath at $100^{\circ} \mathrm{C}$. The mixture was extracted with toluene and absorbance was measured at $520 \mathrm{~nm}$ using L-proline as a standard.

Cys content in leaves was determined spectrophotometrically by adopting the method of Gaitonde [31]. Fresh leaf $(0.5 \mathrm{~g})$ tissue was homogenized in 5\% (w:v) ice-cold perchloric acid. The suspension was centrifuged at $2,800 \times \mathrm{g}$ for $1 \mathrm{~h}$ at $5^{\circ} \mathrm{C}$, and the supernatant was filtered. One $\mathrm{mL}$ of filtrate was treated with acid ninhydrin reagent and the absorption was read at $560 \mathrm{~nm}$. The amount of Cys was calculated using calibration curve obtained for standard Cys.

GSH content was determined following the method of Anderson [32]. Fresh leaves (0.5 g) were homogenized in $2.0 \mathrm{~mL}$ of $5 \%$ sulphosalicylic acid under cold conditions. The homogenate was centrifuged at $10,000 \times \mathrm{g}$ for $10 \mathrm{~min}$. To $0.5 \mathrm{~mL}$ of supernatant, $0.6 \mathrm{~mL}$ of phosphate buffer $(100 \mathrm{mM}, \mathrm{pH}$ 7.0) and $40 \mu \mathrm{L}$ of 5'5'-dithiobis-2-nitrobenzoic acid (DTNB) were added. After $2 \mathrm{~min}$ the absorbance was read at $412 \mathrm{~nm}$.

\section{Data Analysis}

All experimental data as means of three replicates were processed through Origin Pro. 8.0. One-way ANOVA was used to calculate statistical significance followed by Dunnett's test as a post-hoc test to independently compare each exposure group. All statistical analyses were run separately using SPSS 16.0 software, and $\mathrm{p}$ value of less than 0.05 was considered to be statistically significant. The data were shown as mean \pm standard error (SE).

\section{Results}

\section{Cadmium Content in Roots, Stems, and Leaves}

Cd content in roots and stems generally declined with increasing $\mathrm{S}$ concentration following a dose-response relationship, whereas in leaves, $\mathrm{Cd}$ levels showed the opposite trend (Fig. 1). As the S levels increased, 


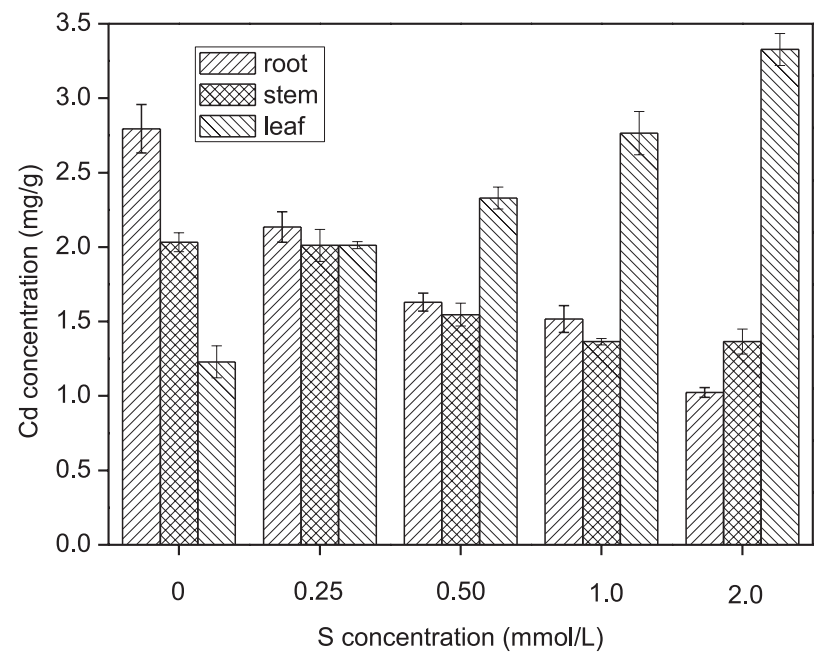

Fig. 1. Cd concentrations in different parts of $H$. verticillata after $7 \mathrm{~d}$ exposure to $\mathrm{Cd}$.

the Cd content decreased from $2.794 \mathrm{mg} / \mathrm{g}$ to $1.023 \mathrm{mg} / \mathrm{g}$ in roots and decreased from 2.023 to $1.365 \mathrm{mg} / \mathrm{g}$ in stems, respectively; however, $\mathrm{Cd}$ content in leaf increased from $1.229 \mathrm{mg} / \mathrm{g}$ to $3.329 \mathrm{mg} / \mathrm{g}$. This indicated that $\mathrm{S}$ supply might inhibit $\mathrm{Cd}$ assimilation in roots while stimulating $\mathrm{Cd}$ accumulation in leaves. Significant correlation was found between $\mathrm{Cd}$ concentrations in leaves and $\mathrm{S}$ concentration in the medium $(\mathrm{R}=0.979$, $\mathrm{p}<0.01)$.

\section{Effect of Sulfur on Subcellular Distribution of Cadmium}

As shown in Table 1, most $\mathrm{Cd}$ accumulated in soluble fractions and in cell walls in $H$. verticillata, with less $\mathrm{Cd}$ present in organelle fractions (Table 1). Analysis of Cd content in leaves at the subcellular level showed that $\mathrm{Cd}$ was stored mainly in the soluble fraction (71.9-88.2\%) and in smaller quantities in cell wall (6.1-22.4\%) and in cell organelles (4.8-6.9\%). As $\mathrm{S}$ concentration increased, $\mathrm{Cd}$ contents in root-soluble fractions and cell walls declined gradually; however, $\mathrm{Cd}$ content increased remarkably in cell walls and soluble fractions in leaves. Significant correlation was found between $\mathrm{S}$ concentration and $\mathrm{Cd}$ concentrations in cell walls or the soluble fractions in leaves, which indicated that $\mathrm{S}$ played an important role in $\mathrm{Cd}$ accumulation and detoxification in $H$. verticillata.

\section{Effect of Sulfur on Chemical Forms of Cadmium}

The different concentration of chemical forms of $\mathrm{Cd}$ in leaf, root, and stem of $H$. verticillata are shown in Figs 2, 3, and 4, respectively. The results clearly indicate that chemical forms of $\mathrm{Cd}$ extracted with $1 \mathrm{M} \mathrm{NaCl}$ $\left(\mathrm{F}_{\mathrm{NaCl}}\right)$ and $2 \% \mathrm{HAc}\left(\mathrm{F}_{\mathrm{HAC}}\right)$ were predominant in all parts of $H$. verticillata. The chemical forms of $\mathrm{Cd}$ extracted with $1 \mathrm{M} \mathrm{NaCl}$ in leaves increased from $1.053 \mathrm{mg} / \mathrm{g}$

Table 1. Subcellular distribution of $\mathrm{Cd}$ in different parts of $H$. verticillata after $7 \mathrm{~d}$ exposure; the different letters represent significant differences at $\mathrm{p}<0.05$ level under five $\mathrm{S}$ levels.

\begin{tabular}{|c|c|c|c|c|c|}
\hline \multirow{2}{*}{$\begin{array}{c}\text { Parts of } \\
\text { H. verticillata }\end{array}$} & \multirow{2}{*}{ S Level } & \multicolumn{4}{|c|}{$\mathrm{Cd}$ in subcellular fractions $(\mathrm{mg} / \mathrm{g}, \mathrm{FW})$} \\
\hline & & Cell wall & Cell organelles & Soluble fraction & Total \\
\hline \multirow{5}{*}{ Leaf } & S1 & $0.102 \pm 0.021 \mathrm{c}$ & $0.059 \pm 0.022 \mathrm{a}$ & $1.047 \pm 0.051 \mathrm{~b}$ & $1.207 \pm 0.094 \mathrm{~b}$ \\
\hline & S2 & $0.126 \pm 0.032 \mathrm{c}$ & $0.117 \pm 0.037 \mathrm{a}$ & $1.821 \pm 0.085 \mathrm{a}$ & $2.064 \pm 0.154 \mathrm{a}$ \\
\hline & S3 & $0.307 \pm 0.022 \mathrm{~b}$ & $0.165 \pm 0.069 \mathrm{a}$ & $1.905 \pm 0.116 \mathrm{a}$ & $2.377 \pm 0.207 \mathrm{a}$ \\
\hline & S4 & $0.535 \pm 0.102 \mathrm{a}$ & $0.150 \pm 0.093 \mathrm{a}$ & $2.062 \pm 0.293 \mathrm{a}$ & $2.745 \pm 0.488 \mathrm{a}$ \\
\hline & S5 & $0.724 \pm 0.135 \mathrm{a}$ & $0.182 \pm 0.072 \mathrm{a}$ & $2.326 \pm 0.307 \mathrm{a}$ & $3.232 \pm 0.514 \mathrm{a}$ \\
\hline \multirow{5}{*}{ Root } & S1 & $0.433 \pm 0.027 \mathrm{a}$ & $0.117 \pm 0.003 \mathrm{a}$ & $2.280 \pm 0.421 \mathrm{a}$ & $2.829 \pm 0.451 \mathrm{a}$ \\
\hline & S2 & $0.382 \pm 0.051 \mathrm{a}$ & $0.134 \pm 0.011 \mathrm{a}$ & $1.689 \pm 0.279 \mathrm{a}$ & $2.205 \pm 0.241 \mathrm{a}$ \\
\hline & S3 & $0.358 \pm 0.100 \mathrm{a}$ & $0.120 \pm 0.020 \mathrm{a}$ & $1.172 \pm 0.185 \mathrm{~b}$ & $1.649 \pm 0.305 \mathrm{a}$ \\
\hline & S4 & $0.260 \pm 0.045 \mathrm{a}$ & $0.097 \pm 0.006 \mathrm{~b}$ & $1.143 \pm 0.164 \mathrm{~b}$ & $1.499 \pm 0.215 \mathrm{a}$ \\
\hline & S5 & $0.203 \pm 0.008 \mathrm{a}$ & $0.056 \pm 0.010 \mathrm{c}$ & $0.930 \pm 0.107 \mathrm{~b}$ & $1.188 \pm 0.125 \mathrm{a}$ \\
\hline \multirow{5}{*}{ Stem } & S1 & $0.368 \pm 0.052 \mathrm{a}$ & $0.090 \pm 0.010 \mathrm{a}$ & $1.761 \pm 0.125 \mathrm{a}$ & $2.219 \pm 0.187 \mathrm{a}$ \\
\hline & S2 & $0.313 \pm 0.039 \mathrm{a}$ & $0.075 \pm 0.016 \mathrm{a}$ & $1.710 \pm 0.197 \mathrm{a}$ & $2.099 \pm 0.252 \mathrm{a}$ \\
\hline & S3 & $0.291 \pm 0.091 \mathrm{a}$ & $0.065 \pm 0.019 \mathrm{a}$ & $1.163 \pm 0.189 \mathrm{~b}$ & $1.519 \pm 0.299 b$ \\
\hline & S4 & $0.299 \pm 0.027 \mathrm{a}$ & $0.063 \pm 0.025 \mathrm{a}$ & $1.030 \pm 0.050 \mathrm{~b}$ & $1.393 \pm 0.102 \mathrm{~b}$ \\
\hline & S5 & $0.240 \pm 0.036 \mathrm{a}$ & $0.063 \pm 0.036 \mathrm{a}$ & $1.156 \pm 0.147 \mathrm{~b}$ & $1.459 \pm 0.219 \mathrm{~b}$ \\
\hline
\end{tabular}


to $2.334 \mathrm{mg} / \mathrm{g}$, when $\mathrm{S}$ concentration increased from $0 \mathrm{mmol} / \mathrm{L}$ to $2 \mathrm{mmol} / \mathrm{L}$. This result demonstrated that as S supply increased, inorganic forms of $\mathrm{Cd}$ decreased, and the proportion of $\mathrm{Cd}$ associated with pectates and proteins increased, indicating that $\mathrm{S}$ stimulated the production of sulfhydryl proteins, which then chelated more $\mathrm{Cd}$. The chemical forms of $\mathrm{Cd}$ extracted with $0.6 \mathrm{M} \mathrm{HCl}$ increased from $0.39 \mathrm{mg} / \mathrm{g}$ to $0.64 \mathrm{mg} / \mathrm{g}$, and the proportion of $\mathrm{Cd}$ extracted by $0.6 \mathrm{M} \mathrm{HCl}$ increased from $2.53 \%$ to $4.67 \%$, suggesting that chelation by oxalate could be an essential detoxification mechanism for H.verticillata to tolerate $\mathrm{Cd}$ in the presence of $\mathrm{S}$. The chemical forms of Cd extracted with $1 \mathrm{M} \mathrm{NaCl}$ decreased from $2.256 \mathrm{mg} / \mathrm{g}$ to $0.767 \mathrm{mg} / \mathrm{g}$ in roots, and decreased from $1.760 \mathrm{mg} / \mathrm{g}$ to $0.984 \mathrm{mg} / \mathrm{g}$ in stems when $\mathrm{S}$ concentration increased from $0 \mathrm{mmol} / \mathrm{L}$ to $2 \mathrm{mmol} / \mathrm{L}$, indicating that $\mathrm{S}$ supply may help $\mathrm{Cd}$ transfer to leaves.
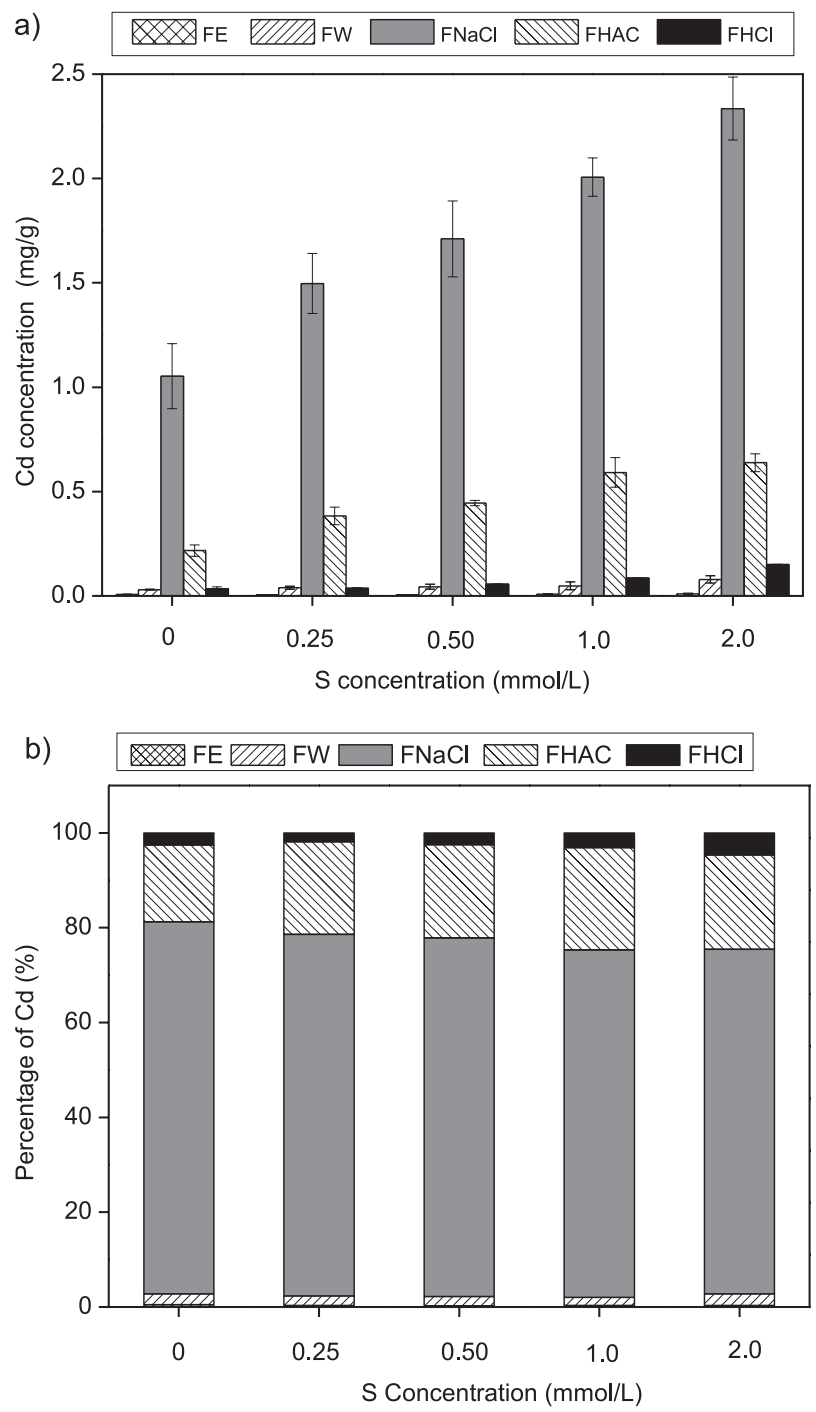

Fig. 2. Cd concentrations a) and percentages b) of different chemical forms of $\mathrm{Cd}$ in leaves of $H$. verticillata after $7 \mathrm{~d}$ exposure to $\mathrm{Cd}$.

\section{Relationship between Subcellular Distribution and Chemical Forms of Cadmium}

The correlations between subcellular fractions and chemical forms of $\mathrm{Cd}$ in $H$. verticillata were determined. In leaves, very significant correlation of $\mathrm{Cd}$ concentrations was found between cell walls and the chemical forms extracted with $\mathrm{HAc}, \mathrm{HCl}$, and $\mathrm{NaCl}$ (Fig. 5), with correlation coefficients of $0.985,0.964$, and $0.957(\mathrm{p}<0.01)$, respectively. Very significant correlation of $\mathrm{Cd}$ concentration was also found between the soluble fractions and the chemical forms extracted with $\mathrm{NaCl}$ and $\mathrm{HCl}$, with correlation coefficient of 0.977 and $0.974(\mathrm{p}<0.01)$. In roots, significant correlation of $\mathrm{Cd}$ concentration was found between cell wall and chemical forms extracted with $\operatorname{HAc}(\mathrm{R}=0.966, \mathrm{p}<0.01)$ or between soluble fractions and chemical forms extracted with $\mathrm{NaCl}(\mathrm{R}=0.967, \mathrm{p}<0.01)$. In stems, the correlations between subcellular fractions and chemical forms of $\mathrm{Cd}$ were quite similar to those in roots. These results
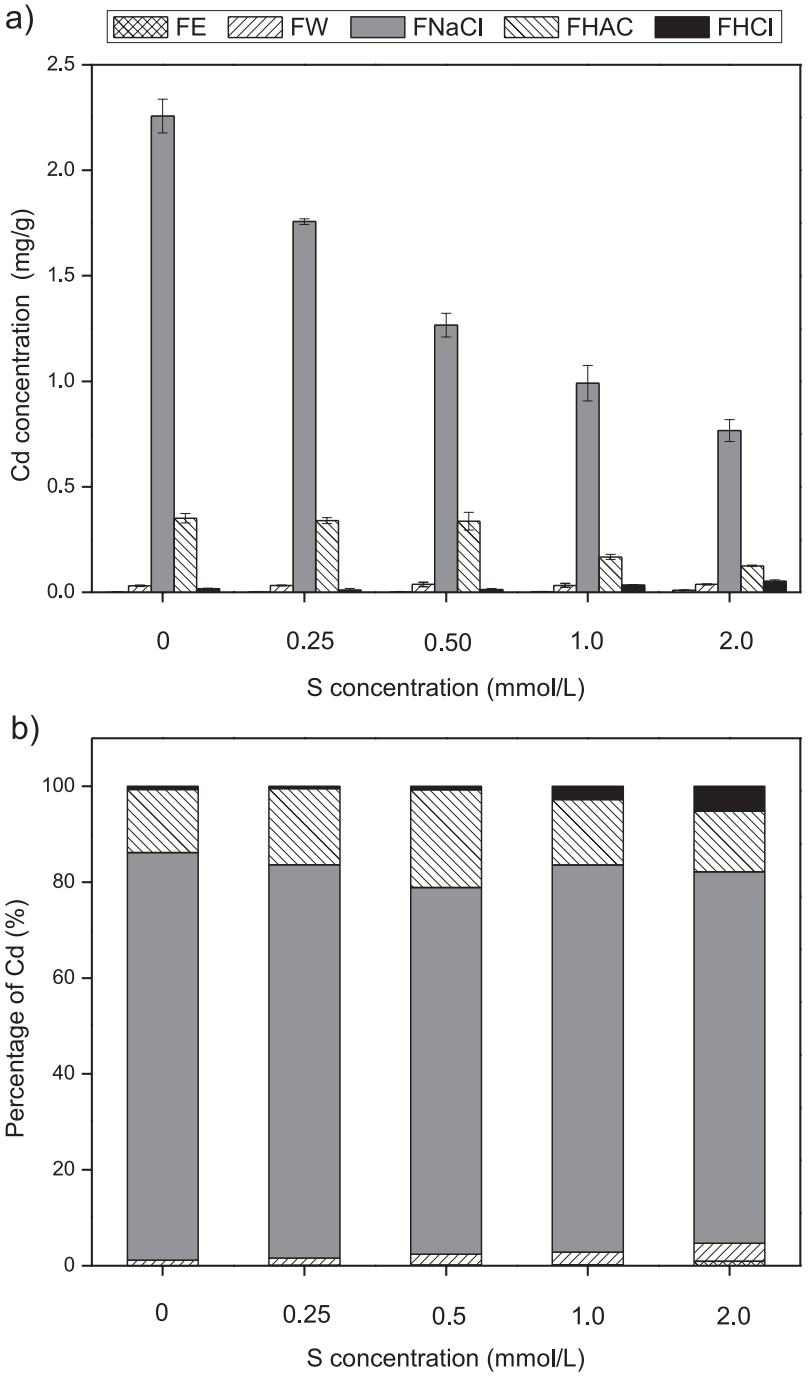

Fig. 3. Cd concentrations a) and percentages b) of different chemical forms of $\mathrm{Cd}$ in roots of $H$. verticillata after $7 \mathrm{~d}$ exposure to $\mathrm{Cd}$. 

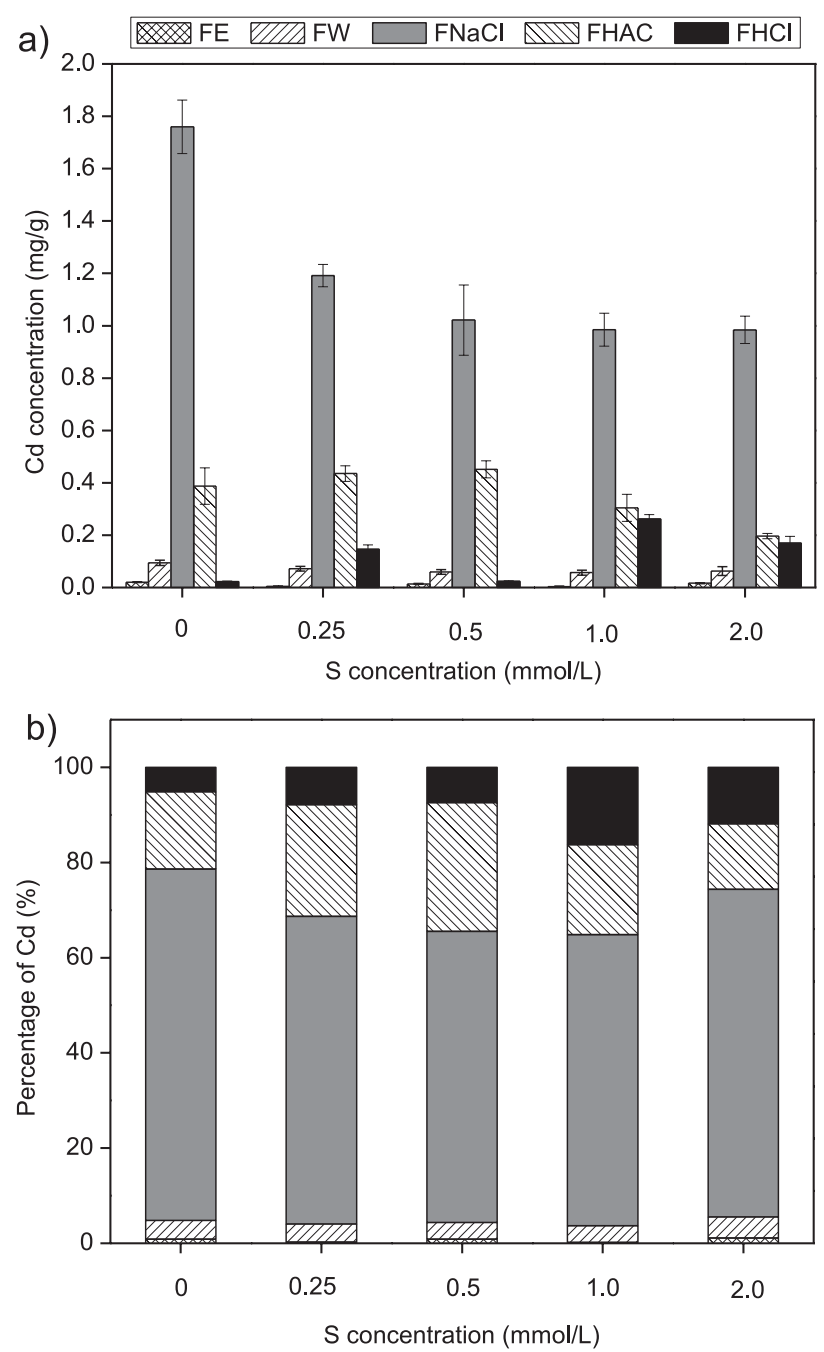

Fig. 4. Cd concentrations a) and percentages b) of different chemical forms of $\mathrm{Cd}$ in stems of $H$. verticillata after $7 \mathrm{~d}$ exposure to $\mathrm{Cd}$.

indicated that $\mathrm{Cd}$ in the soluble fraction or cell walls was mainly in the form of pectates/protein, phosphate, and oxalate.

\section{Influence of S on Contents of Proline, Cys, and GSH under Cd Stress}

The content of proline in $H$. verticillata under $\mathrm{S}$ conditions was significantly higher than that of the control $(\mathrm{P}<0.05)$, and the proline content was increased with the application of $\mathrm{S}$ under $\mathrm{Cd}$ stress. With the treatment of $2 \mathrm{mmol} \mathrm{L}^{-1} \mathrm{~S}$, the content of proline was about 2.1 times compared to control under no $\mathrm{S}$ condition (Fig. 6a). As to the treatment for 7 days, the content of Cys increased with the application of $\mathrm{S}$ under $\mathrm{Cd}$ stress in comparison to control. At $2 \mathrm{mmol} \mathrm{L}^{-1} \mathrm{~S}$ treatment level, $\mathrm{S}$ application increased the content of Cys by $85 \%$ compared to control under no S condition (Fig. 6b). The GSH content of $H$. verticillata under each treatment was significantly higher than that of the control $(\mathrm{P}<0.05)$, and the GSH content of $H$. verticillata was firstly increased and then decreased with the increment of $\mathrm{S}$ concentration (Fig. 6c). At $1 \mathrm{mmol} \mathrm{L}^{-1} \mathrm{~S}$ treatment level, the GSH content of $H$. verticillata achieved the highest level of about 3.1 times as compared with the control.

\section{The Correlation Matrix for S Concentration and Cd Content with the Physiological Characteristics}

The correlations of $\mathrm{S}$ concentration and $\mathrm{Cd}$ content with the physiological characteristics were determined (Table 2). In this study, the proline and Cys contents in leaves of $H$. verticillata were significantly correlated with $\mathrm{S}$ concentrations in the medium and the $\mathrm{Cd}$ content in leaves $(\mathrm{P}<0.05)$. Furthermore, significant correlation was found between $\mathrm{Cd}$ contents and GSH contents in leaves $(\mathrm{P}<0.01)$.

\section{Discussion}

Aquatic plants are useful vehicles for treating heavy metal pollution in water. Islam et al. observed a higher $\mathrm{Cd}$ content in leaf than in other tissues in Micranthemum umbrosum. However, Weng et al. [33] observed higher $\mathrm{Cd}$ content in roots than in other tissues in Kandelia obovata. These results indicate that heavy metals could be accumulated in different plant parts. Analysis of $\mathrm{Cd}$ content in root, stem, and leaf of $H$. verticillata showed that $\mathrm{S}$ could affect the distribution of $\mathrm{Cd}$ in different parts of $H$. verticillata. S supply significantly restrained $\mathrm{Cd}$ accumulation in roots and stems of $H$. verticillata. Other reports have shown that $\mathrm{S}$ could inhibit $\mathrm{Cd}$ from entering rice roots, suggesting that $\mathrm{S}$ supply enhances the formation of iron plaque - a protective defense of rice roots against heavy metal uptake [34]. Hassan et al. [20] observed that S supplementation decreased $\mathrm{Cd}$ accumulation and alleviated Cd toxicity in plants. Such results were similar to those observed in the present study. Furthermore, the shoots of $H$. verticillata have the ability to take up metals directly from water since they are completely inundated and have a very thin cuticle. Hence, we deduced that differences in $\mathrm{Cd}$ accumulation in $H$. verticillata tissues with increasing S supply might be explained by the following mechanisms: 1) S supply changed the availability of $\mathrm{Cd}$ and 2) $\mathrm{S}$ induced the production of antioxidants, which could chelate $\mathrm{Cd}$, forming complexes that alleviate $\mathrm{Cd}$ toxicity in leaves.

In our study, $\mathrm{Cd}$ analysis at the subcellular level of $H$. verticillata roots demonstrated that a large proportion of $\mathrm{Cd}(80.6-71.1 \%)$ was stored in the soluble fraction (Table 1), which has a high migration capacity and will further translocate to the shoot [35]. As the vacuole is a dynamic organelle that comprises as much as $90 \%$ of the total cell volume in some cell types, we may deduce that the vacuole was the predominant sink for $\mathrm{Cd}$. These results were in line with those presented for Cd-treated eucalyptus [36], barley [29], and soybean plants [37]. In 

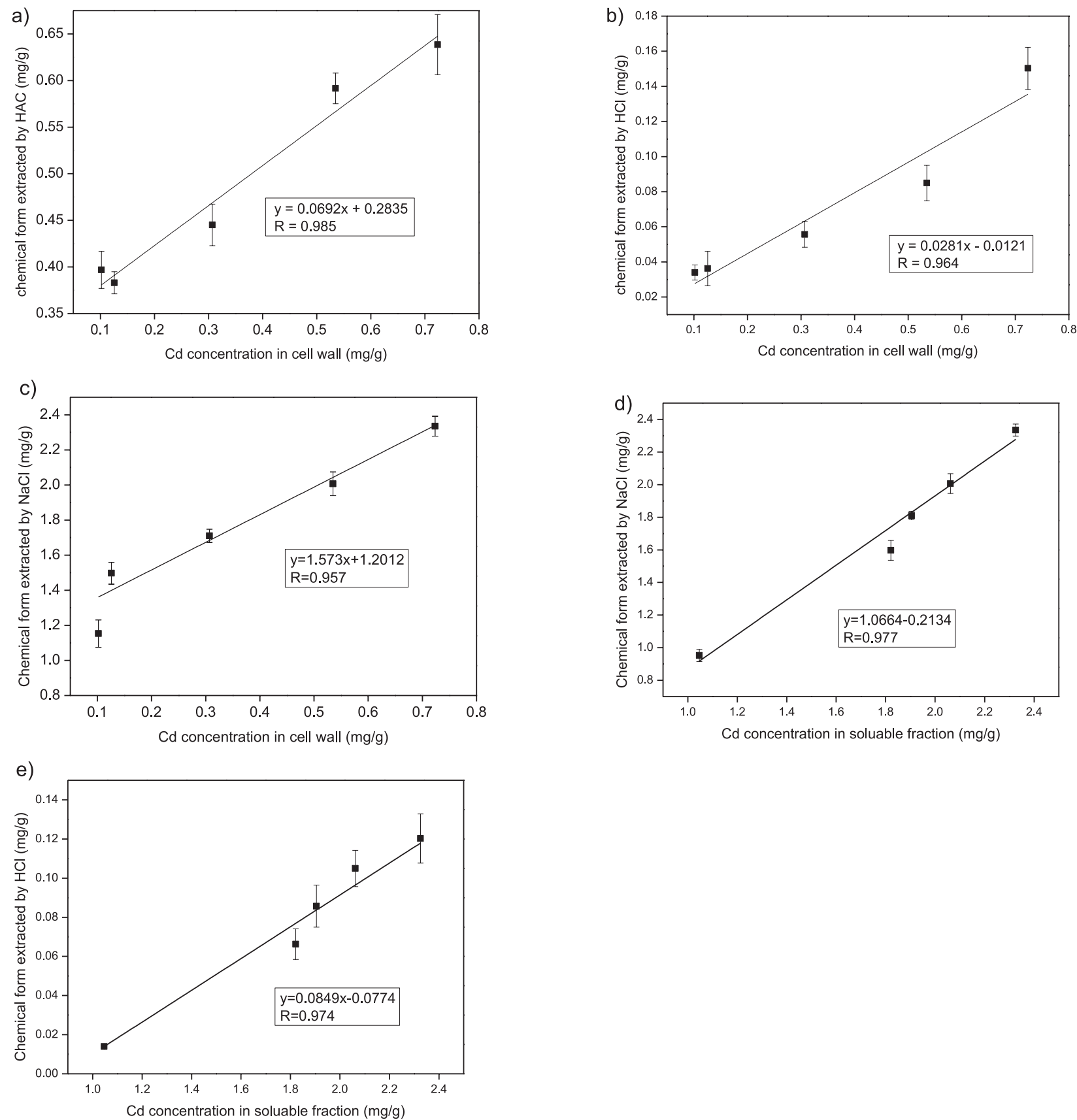

Fig. 5. Correlation of Cd between subcellular distribution and chemical forms in leaf: a) $F_{\mathrm{HAc}}$ versus Cd in cell wall; b) $\mathrm{F}_{\mathrm{HCl}}$ versus Cd in cell wall; c) $\mathrm{F}_{\mathrm{NaCl}}$ versus $\mathrm{Cd}$ in cell wall; d) $\mathrm{F}_{\mathrm{NaCl}}$ versus $\mathrm{Cd}$ in soluble fraction; e) $\mathrm{F}_{\mathrm{HCl}}$ versus $\mathrm{Cd}$ in soluble fraction.

contrast to the present results, several studies found that the main site of $\mathrm{Cd}$ accumulation in plant roots is the apoplast, particularly cell walls [23]. These differences may be attributed to the distinct $\mathrm{Cd}$ concentrations used by the different authors and also to the variable levels of Cd tolerance of plants.

Plant cell walls, which function as the first barrier protecting the protoplast from $\mathrm{Cd}$ toxicity, are mainly composed of polyose (including cellulose, hemicellulose, and pectin) and protein, providing negative charge sites on their surfaces. Therefore, plant cell walls can bind $\mathrm{Cd}$ ions and restrict their transportation across cytomembrane. In our study, a proportion (6.1-22.4\%) of
Cd was bound to the cell wall fraction, suggesting that the cell wall is another large buffer that can accumulate heavy metals and is believed to play a role in metal tolerance. Meanwhile, we found that in plant leaf, the proportion of $\mathrm{Cd}$ in the cell wall fraction increased following the increase of $\mathrm{S}$ concentration in solution (Table 1), indicating that the cell walls prevented $\mathrm{Cd}$ entry into the cells. The cell walls can work as a barrier and effectively sequestrate heavy metal ions. Therefore, the cell walls are another key factor in defense against heavy metal toxicity of aquatic plants.

$\mathrm{Fu}$ et al. [38] observed the subcellular distribution of $\mathrm{Cd}$ in Phytolacca americana L. and deduced that 
a)

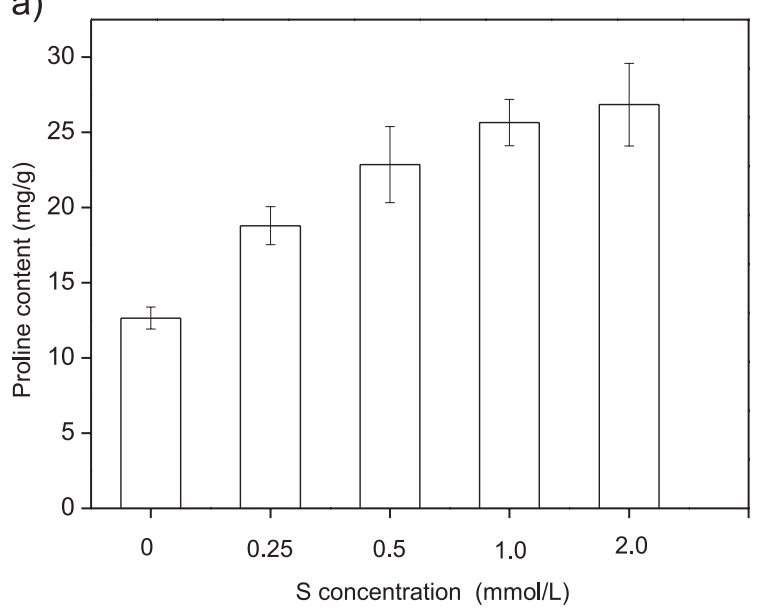

b)

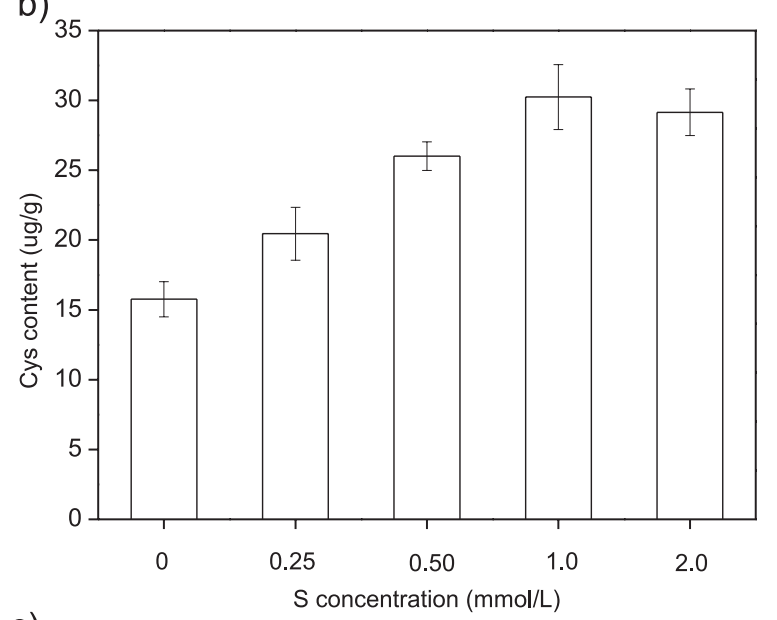

c)

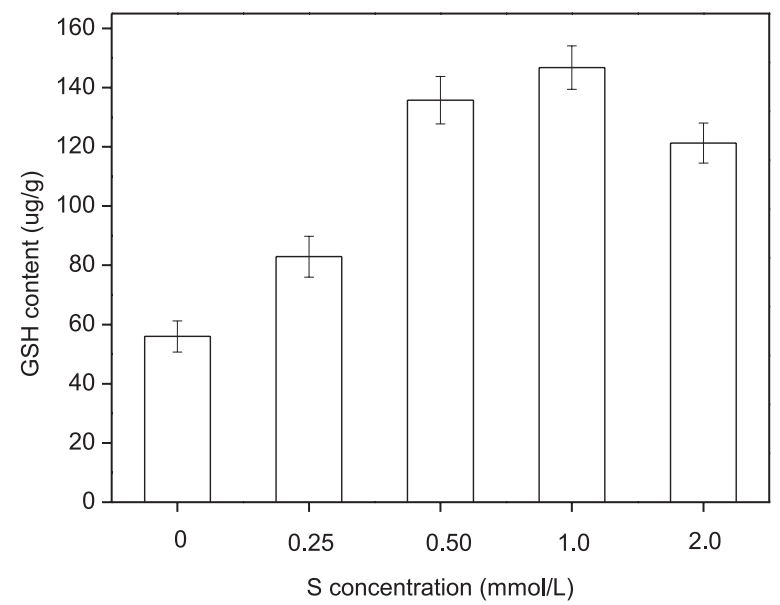

Fig. 6. Effects of S application on proline, Cys, and GSH content in Cd-treated H. verticillata (a: proline; b: Cys; c: GSH) .

both vacuoles and cell walls might be involved in Cd-tolerance mechanisms to protect metabolically active cellular compartments. We obtained similar experimental results. It can be inferred that the variability of $\mathrm{Cd}$ concentration in the cell may be regulated by three processes: $\mathrm{Cd}$ binding to biological molecules, chelation of $\mathrm{Cd}$ through oxalate, and cellular compartmentalization in vacuoles.
Table 2. The correlation matrix for $\mathrm{S}$ concentration and $\mathrm{Cd}$ content with the physiological characteristics of $H$. verticillata.

\begin{tabular}{|c|c|c|c|c|c|}
\hline & S & Cd & Proline & Cys & GSH \\
\hline S & 1 & & & & \\
\hline Cd & 0.523 & 1 & & & \\
\hline Proline & $0.872^{*}$ & $0.893^{*}$ & 1 & & \\
\hline Cys & $0.849^{*}$ & $0.91^{*}$ & $0.985^{* *}$ & 1 & \\
\hline GSH & 0.589 & $0.941^{* *}$ & $0.909^{*}$ & $0.949^{* *}$ & 1 \\
\hline
\end{tabular}

* Correlation is significant at the 0.05 level (2-tailed).

** Correlation is significant at the 0.01 level (2-tailed).

The chemical forms of $\mathrm{Cd}$ are closely related to their biological toxicity. For instance, water-soluble $\mathrm{Cd}$ in inorganic form (extracted with $80 \%$ ethanol) and organic form (extracted with deionized water) has stronger harmful effects than the undissolved $\mathrm{Cd}$ in pectates/protein (extracted with $1 \mathrm{M} \mathrm{NaCl}$ ) and phosphate (extracted with 2\% HAc) [23, 38]. For $H$. verticillata, the major chemical form of $\mathrm{Cd}$ was $\mathrm{Cd}$ in pectates/protein, followed by the undissolved Cd-phosphate complexes. The $\mathrm{Cd}$ forms of pectates/ protein and phosphate were mainly associated with the vacuoles and cell walls of the $H$. verticillata. The $80 \%$ ethanol-extractable $\mathrm{Cd}$ consisted of inorganic forms, which contributed the most to $\mathrm{Cd}$ stress in plants, whereas $\mathrm{NaCl}$-extractable (organic) $\mathrm{Cd}$ might be responsible for plant adaptation to $\mathrm{Cd}$ stress [23]. Thus, inorganic $\mathrm{Cd}$ was changed to organic ( $\mathrm{NaCl}-$ extractable) $\mathrm{Cd}$ after $\mathrm{S}$ supply increased, causing less harm to $H$. verticillata. In addition, $H$. verticillata leaves have an intrinsically high content of oxalate [39]. Chelation of $\mathrm{Cd}$ by oxalate could be an essential detoxification mechanism to render excess $\mathrm{Cd}$ inactive; therefore, oxalic acid could play an important role in $\mathrm{Cd}$ accumulation and detoxification in $H$. verticillata.

The formation of Cd-phosphate complexes is an important detoxification mechanism for plants. $\mathrm{P}$ content was increased in the cell of Rhodotorula sp. Y11 under $\mathrm{Cd}$ toxicity [40]. Polyphosphate accumulation in extraradical hyphae enhances the resistance of Rhizophagus irregularis against Cd [41]. Cunninghamella elegans may accumulate polyphosphate as a detoxification mechanism to precipitate and tolerate $\mathrm{Cd}$ [42]. Penicillium chrysogenum deposited $\mathrm{Cd}$ inside or outside of the cells by forming $\mathrm{Cd}_{3}\left(\mathrm{PO}_{4}\right)_{2}$ with phosphoryl. The conspicuous phosphorus peak in the EDAX spectra of Rhizopus oligosporus indicated that $\mathrm{Cd}$ was deposited as Cd-phosphate complexes. We suggest that $H$. verticillata can form undissolved $\mathrm{Cd}$ in phosphate on the cell walls to decrease $\mathrm{Cd}$ toxicity. Forming Cd-phosphate complexes would allow $H$. verticillata to tolerate $\mathrm{Cd}$ stress by accumulating $\mathrm{Cd}$ on the cell walls of $H$. verticillata. Although P uptake is affected by many factors, including sulfur supply, the relationship between phosphate or polyphosphate 
and Cd-detoxifying mechanisms in $H$. verticillata remains unclear and needs further study.

The complexation of metals with organic ligands results in decreased free ion activity, thus reducing their toxicity. The organic ligands involved in compartmenting $\mathrm{Cd}$ in vacuoles are mainly sulfurrich peptides [43]. At high $\mathrm{S}$ levels, the concentration of $\mathrm{NaCl}$-extracted $\mathrm{Cd}\left(\mathrm{F}_{\mathrm{NaCl}}\right)$ was higher than that of other $\mathrm{Cd}$ forms, which mirrored the accumulation of $\mathrm{Cd}$ in soluble fractions and cell walls. Therefore, we can assume that $H$. verticillata adapts to $\mathrm{Cd}$ stress through the larger percentage of $\mathrm{NaCl}$-extractable $\mathrm{Cd}$ in leaves, which supports the theory that compartmentation in vacuoles and sequestration in cell walls is crucial for the detoxification of $\mathrm{Cd}$. The difference of percentage of chemical forms between root and leaf in $H$. verticillata was because the existence of S led to higher synthesis of antioxidants in plants [33], allowing $\mathrm{Cd}$ to transfer from roots to leaves. The relationship between subcellular distribution and chemical forms was similar in roots and stems, indicating that subcellular distribution and chemical forms of $\mathrm{Cd}$ were relevant to alleviate $\mathrm{Cd}$ toxicity.

It has been shown that plants resist stress by increasing components of their intrinsic defensive system. For example, some antioxidants like proline may play a role in inducing resistance to metals [44]. Proline accumulation is an adaptive strategy of plants to stressful environments which maintains the osmotic balance, scavenges excess free radicals, stabilizes cell membrane structure and function [45], regulates cellular redoxpotential [46], sustains PSII electron transport [47], and increases $\mathrm{N}$ remobilization and $\mathrm{N}$-use efficiency in B. napus [48]. Up-regulation of proline is often encountered in plants under heavy metal stress, and the possibility of proline involvement in the chelation of metal ions is also indicated [49]. Studies on $\mathrm{S}$ have shown that they could improve photosynthetic efficiency and proline accumulation under salt stress in B. juncea and under chilling stress in Cucumis sativus [50]. In the present study, the level of proline also increased significantly in $\mathrm{S}$ application plants. Hence, proline accumulation would have acted as a supporting mechanism for the capacity of proline to quench ROS.

The results presented herein show that intercellular $\mathrm{Cd}$ enhanced Cys and GSH contents. On the other hand, alleviation of $\mathrm{Cd}$ toxicity in high $\mathrm{S}$-treated $H$. verticillata was due to higher contents of Cys and GSH. Similarly, Mera et al. [16] reported that thiolrich sulphur containing compounds such as Y-GluCys, Cys, GSH, and phytochelatins developed tolerance mechanisms in microalga under $\mathrm{Cd}$ stress. Overall results indicate that $\mathrm{S}$ addition up-regulates these antioxidants - particularly S-containing non-enzymatic antioxidants, which prevent $\mathrm{Cd}$-induced oxidative modification in test living organisms against $\mathrm{Cd}$. Up-regulation in antioxidants has been reported by several researchers under various abiotic stresses [34,
51-53]. In this study, the GSH contents of $H$. verticillata increased with the increment of $\mathrm{S}$ concentration from 0.25 to $1 \mathrm{mmol} \mathrm{L}^{-1} \mathrm{~S}$ treatment level, which reflected that $H$. verticillata accelerated synthesizing GSH in order to improve their tolerant capacity. The GSH contents of $H$. verticillata were first increased and then decreased with the increment of $\mathrm{S}$ concentration, perhaps due to the huge consumption of GSH for detoxification, or the inhibition from excessive ROS induced by $\mathrm{Cd}$ stress, or the involvement of GSH in PC synthesis as PCs are synthesized using GSH as a precursor [54]. Therefore, $\mathrm{S}$ supply might promote the synthesis of sulfhydryl proteins such as GSH and cysteine, and then chelate $\mathrm{Cd}$ for transfer to vacuoles, which might be an important mechanism of heavy metal detoxification.

\section{Conclusions}

After combined treatments of $\mathrm{Cd}$ and S, Cd mainly accumulated in $H$. verticillata leaves. As $\mathrm{S}$ supply was increased, $\mathrm{Cd}$ content decreased in roots while it increased in leaves. Cd mainly existed in the soluble fractions and cell walls of $H$. verticillata. Furthermore, the $\mathrm{Cd}$ contents in root-soluble fractions and cell walls declined gradually as $\mathrm{S}$ concentration increased. By comparison, the $\mathrm{Cd}$ contents in leaf cell walls and soluble fractions increased remarkably, which indicated that $\mathrm{S}$ supply might promote the transfer of $\mathrm{Cd}$ into vacuoles in leaves. At high $\mathrm{S}$ levels, the concentration of $\mathrm{NaCl}$-extracted $\mathrm{Cd}\left(\mathrm{F}_{\mathrm{NaCl}}\right)$ in leaves was higher than that of other $\mathrm{Cd}$ forms. This observation was in good agreement with the accumulation of $\mathrm{Cd}$ in soluble fractions and cell walls. The formation of Cd-phosphate complexes or $\mathrm{Cd}$ oxalate could be considered another important detoxification mechanism in $H$. verticillata. Exogenous $\mathrm{S}$ played an important role in ameliorating the $\mathrm{Cd}$ tolerance of $H$. verticillata by promoting proline accumulation, the contents of Cys, and GSH. Our results provide insights into the physiological mechanism of $\mathrm{S}$ in regulating the uptake, translocation, and tolerance of $\mathrm{Cd}$ in plants. Hence, $\mathrm{S}$ can potentially be used as a physiological tool in sustainable development of phytoremediation. However, studies are needed to evaluate the $\mathrm{S}$ nutrition effect in phytoremediation involving longer-duration assays.

\section{Acknowledgements}

This study was financially supported by the Natural Science Foundation of Fujian Province of China (grant Nos. 2016J01695 and 2015J01651), the Pre-research Foundation for the Natural Science Funds in XMUT (grant No. XYK201420), and the National Natural Science Funds of China (grant Nos. 51378446 and 51008261). 


\section{Conflict of Interest}

The authors declare no conflict of interest

\section{References}

1. TOROK A., GULYAS Z., SZALAI G., KOCSY G., MAJDIK C. Phytoremediation capacity of aquatic plants is associated with the degree of phytochelatin polymerization, J. Hazard. Mater. 299, 371, 2015.

2. ISIAM M. S., SAITO T., KURASAKI M. Phytofiltration of arsenic and cadmium by using an aquatic plant, Micranthemum umbrosum: Phytotoxicity, uptake kinetics, and mechanism, Ecotox. Environ. Safe. 112, 193, 2015.

3. MERA R., TORRES E., ABALDE J. Influence of sulphate on the reduction of cadmium toxicity in the microalga Chlamydomonas moewusii, Ecotox. Environ. Safe. 128, 236, 2016.

4. CHEN S., NICHOLS K.M., POYNTON H.C., SEPULVEDA M.S. MicroRNAs are involved in cadmium tolerance in Daphnia pulex, Aquat. Toxicol. 175, 241, 2016.

5. XU Q., MIN H., CAI S., FU Y., SHA S., XIE K., DU K. Subcellular distribution and toxicity of cadmium in Potamogeton crispus L., Chemosphere 89 (1), 114, 2012.

6. CALDERON B., FULLANA A. Heavy metal release due to aging effect during zero valent iron nanoparticles remediation, Water Res. 83, 1, 2015.

7. MALEKI H. Recent advances in aerogels for environmental remediation applications: A review, Chem. Eng. J. 300, 98, 2016.

8. BAHEMMAT M., FARAHBAKHSH M., KIANIRAD M. Humic substances-enhanced electroremediation of heavy metals contaminated soil, J. Hazard. Mater. 312, 307, 2016.

9. YIN H., ZHU J. In situ remediation of metal contaminated lake sediment using naturally occurring, calcium-rich clay mineral-based low-cost amendment, Chem. Eng. J. 285, 112, 2016.

10. MANZATU C., NAGY B., CECCARINI A., IANNELLI R., GIANNARELLI S., MAJDIK C. Laboratory tests for the phytoextraction of heavy metals from polluted harbor sediments using aquatic plants, Mar. Pollut. Bull. 101 (2), $605,2015$.

11. WANG Z., YAO L., LIU G., LIU W. Heavy metals in water, sediments and submerged macrophytes in ponds around the Dianchi Lake, China, Ecotox. Environ. Safe. 107, 200, 2014.

12. RASCIO N., NAVARI-IZZO F. Heavy metal hyperaccumulating plants: How and why do they do it? And what makes them so interesting?, Plant Sci. 180 (2), 169, 2011.

13. GARCIA-GARCIA J.D., SANCHEZ-THOMAS R., MORENO-SANCHEZ R. Bio-recovery of non-essential heavy metals by intra- and extracellular mechanisms in free-living microorganisms, Biotechnol. Adv. 34 (5), 859, 2016.

14. BARRAMEDA-MEDINA Y., MONTESINOS-PEREIRA D., ROMERO L., BLASCO B., RUIZ J.M. Role of GSH homeostasis under $\mathrm{Zn}$ toxicity in plants with different $\mathrm{Zn}$ tolerance, Plant Sci. 227, 110, 2014.

15. SMITH S.D.P. The roles of nitrogen and phosphorus in regulating the dominance of floating and submerged aquatic plants in a field mesocosm experiment, Aquat. Bot. $112,1,2014$
16. MERA R., TORRES E., ABALDE J. Sulphate, more than a nutrient, protects the microalga Chlamydomonas moewusii from cadmium toxicity, Aquat. Toxicol. 148, 92, 2014.

17. ZHANG W., LIN K., ZHOU J., ZHANG W., LIU L., HAN $X$. Spatial distribution and toxicity of cadmium in the joint presence of sulfur in rice seedling, Environ. Toxicol. Phar. 36 (3), 1235, 2013.

18. ANJUM N.A., UMAR S., AHMAD A., IQBALM., KHAN N. A. Sulphur protects mustard (Brassica campestris L.) from cadmium toxicity by improving leaf ascorbate and glutathione, Plant Growth. Regul. 54 (3), 271, 2008.

19. BASHIR H., AHMAD J., BAGHERI R., NAUMAN M., QURESHI M.I. Limited sulfur resource forces Arabidopsis thaliana to shift towards non-sulfur tolerance under cadmium stress, Environ. Exp. Bot. 94, 19, 2013.

20. HASSAN M.J., WANG Z., ZHANG G. Sulfur alleviates growth inhibition and oxidative stress caused by cadmium toxicity in rice, J. Plant. Nutr. 28 (10), 1785, 2005.

21. ZHAN F., HE Y., LI Y., LI T., YANG Y., TOOR G.S., ZHAO Z. Subcellular distribution and chemical forms of cadmium in a dark septate endophyte (DSE), Exophiala pisciphila, Environ. Sci. Pollut. R. 22 (22), 17897, 2015.

22. RAMOS I., ESTEBAN E., LUCENA J.J., GARATE A. Cadmium uptake and subcellular distribution in plants of Lactuca sp. Cd-Mn interaction, Plant Sci. 162 (5), 761, 2002.

23. WANG X., LIU Y., ZENG G., CHAI L., SONG X., MMIN Z., XIAO X. Subcellular distribution and chemical forms of cadmium in Bechmeria nivea (L.) Gaud., Environ. Exp. Bot. 62 (3), 389, 2008.

24. CHEN M., ZHANG L., TUO Y., HE X., LI J., SONG Y. Treatability thresholds for cadmium-contaminated water in the wetland macrophyte Hydrilla verticillata (L.f.) Royle, Ecol. Eng. 96, 178, 2016.

25. XU Q., CHU W., QIU H., FU Y., CAI S., SHA S. Responses of Hydrilla verticillata (L.f.) Royle to zinc: In situ localization, subcellular distribution and physiological and ultrastructural modifications, Plant Physiol. Bioch. 69, 43, 2013.

26. LAFABRIE C., MAJOR K. M., MAJOR C. S., CEBRIAN J. Trace metal contamination of the aquatic plant Hydrilla verticillata and associated sediment in a coastal Alabama creek (Gulf of Mexico - USA), Mar. Pollut. Bull. 68 (1-2), 147, 2013

27. SRIVASTAVAS., MISHRA S., TRIPATHI R. D., DWIVEDI S., GUPTA D. K. Copper-induced oxidative stress and responses of antioxidants and phytochelatins in Hydrilla verticillata (L.f.) Royle, Aquat. Toxicol. 80 (4), 405, 2006.

28. WEIGEL H.J., JAGER H.J. Subcellular distribution and chemical form of cadmium in bean plants, Plant Physiol. 65 (3), 480, 1980.

29. WU F., DONG J., QIAN Q., ZHANG G. Subcellular distribution and chemical form of $\mathrm{Cd}$ and $\mathrm{Cd}-\mathrm{Zn}$ interaction in different barley genotypes, Chemosphere $\mathbf{6 0}$ (10), 1437, 2005.

30. BATES L.S., WALDREN R.P., TEARE I.D. Rapid determination of free proline for water-stress studies, Plant Soil 39 (1), 205, 1973

31. GAITONDE M.K. A spectrophotometric method for the direct determination of cysteine in the presence of other naturally occurring amino acids., Biochem. J. 104 (2), 627, 1967. 
32. ANDERSON M.E. Determination of glutathione and glutathione disulfide in biological samples, Method. Enzymol. 113 (4), 548, 1985.

33. WENG B., XIE X., WEISS D.J., LIU J., LU H., YAN C. Kandelia obovata (S., L.) Yong tolerance mechanisms to cadmium: Subcellular distribution, chemical forms and thiol pools, Mar. Pollut. Bull. 64 (11), 2453, 2012.

34. FAN J., HU Z., ZIADI N., XIA X., WU C. Excessive sulfur supply reduces cadmium accumulation in brown rice (Oryza sativa L.), Environ. Pollut. 158 (2), 409, 2010.

35. LAI H. Subcellular distribution and chemical forms of cadmium in Impatiens walleriana in relation to its phytoextraction potential, Chemosphere 138, 370, 2015.

36. PIETRINI F., IORI V., BIANCONI D., MUGHINI G., MASSACCI A., ZACCHINI M. Assessment of physiological and biochemical responses, metal tolerance and accumulation in two eucalypt hybrid clones for phytoremediation of cadmium-contaminated waters, J. Environ. Manage. 162, 221, 2015.

37. CATALDO D.A., GARLAND T.R., WILDUNG R. E. Cadmium distribution and chemical fate in soybean plants, Plant Physiol. 68 (4), 835, 1981.

38. FU X., DOU C., CHEN Y., CHEN X., SHI J., YU M., XU J. Subcellular distribution and chemical forms of cadmium in Phytolacca americana L., J. Hazard. Mater. 186 (1), 103, 2011.

39. ZHONG Z., WANG H., WANG H., SONG Y., LI H. Effects of arsenic speciations on contents of main organic acids in Hydrilla verticillata and Potamogeton malaianus, Acta. Ecol. Sin. 32 (16), 5002, 2012.

40. LI Z., YUAN H., HU X. Cadmium-resistance in growing Rhodotorula sp. Y11, Bioresource Technol. 99 (5), 1339, 2008.

41. YAO Q., YANG R., LONG L., ZHU H. Phosphate application enhances the resistance of arbuscular mycorrhizae in clover plants to cadmium via polyphosphate accumulation in fungal hyphae, Environ. Exp. Bot. 108, 63, 2014.

42. LIMA M.A.B, FRANCO L.O., SOUZA P.M, NASCIMENTO A.E., SILVA C.A.A., MAIA R. C.C., ROLIM H.M.L., TAKAKI G.M.C. Cadmium tolerance and removal from Cunninghamella elegans related to the polyphosphate metabolism, Int. J. Mol. Sci. 14, 7180, 2013.

43. BHATIA N.P., WAISH K.B., BAKER A.J.M. Detection and quantification of ligands involved in nickel detoxification in a herbaceous $\mathrm{Ni}$ hyperaccumulator Stackhousia tryonii Bailey, J. Exp. Bot. 56 (415), 1343, 2005.

44. LI S., CHEN J., ISIAM E., WANG Y., WU J., YE Z., YAN W., PENG D., LIU D. Cadmium-induced oxidative stress, response of antioxidants and detection of intracellular cadmium in organs of moso bamboo (Phyllostachys pubescens) seedlings, Chemosphere 153, 107, 2016.

45. KISHOR P.B.K., SANGAM S., AMRUTHA R. N., LAXMI P.S., NAIDU K.R., RAO K.R.S.S., RAO S., REDDY K.J., THERIAPPAN P., SREENIVASULU N. Regulation of proline biosynthesis, degradation, uptake and transport in higher plants: Its implications in plant growth and abiotic stress tolerance, Curr. Sci. India 88 (3), 424, 2005.

46. ASHRAF M., FOOLAD M.R. Roles of glycine betaine and proline in improving plant abiotic stress tolerance., Environ. Exp. Bot. 59, 206, 2007.

47. HAMILTON E.W., HECHKATHORN S.A. Mitochondrial adaptations to $\mathrm{NaCl}$. complex $\mathrm{I}$ is protected by antioxidants and small heat shock proteins, whereas complex II is protected by proline and betaine, Plant Physiol. 126 (3), 1266, 2001.

48. ALBERT B., CAHEREC F.L., NIOGRET M.F., FAES P., AVICE J.C., LEPORT L., BOUCHEREAU A. Nitrogen availability impacts oilseed rape (Brassica napus L.) plant water status and proline production efficiency under waterlimited conditions, Planta 236 (2), 659, 2012.

49. KHAN M.I.R., NAZIR F., ASGHER M., PER T.S., KHAN N.A. Selenium and sulfur influence ethylene formation and alleviate cadmium-induced oxidative stress by improving proline and glutathione production in wheat, J. Plant Physiol. 173, 9, 2015.

50. FATMA M., ASGHERM., MASOOD A., KHAN N.A. Excess sulfur supplementation improves photosynthesis and growth in mustard under salt stress through increased production of glutathione, Environ. Exp. Bot. 107, 55, 2014.

51. LIANG T., DING H., WANG G., KANG J., PANG H., LV J. Sulfur decreases cadmium translocation and enhances cadmium tolerance by promoting sulfur assimilation and glutathione metabolism in Brassica chinensis L., Ecotox. Environ. Safe. 124, 129, 2016.

52. CAPALDI F.R., GRATAO P.L., REIS A.R., LIMA L.W., AZEVEDO R.A. Sulfur metabolism and stress defense responses in plants, Trop. Plant Biol. 8 (3-4), 60, 2015.

53. MARIESCHI M., GORBI G., ZANNI C., SARDELLA A., TORELLI A. Increase of chromium tolerance in Scenedesmus acutus after sulfur starvation: Chromium uptake and compartmentalization in two strains with different sensitivities to $\mathrm{Cr}(\mathrm{VI})$, Aquat. Toxicol. 167, 124, 2015.

54. GUPTA M., RAI U.N., TRIPATHI R.D., CHANDRA P. Lead induced changes in glutathione and phytochelatin in Hydrilla verticillata (L.F.) royle, Chemosphere 30 (10), 2011, 1995. 
